\title{
Gender, Animals, and Gaskell's Cousin Phillis
}

\author{
Ayşe ÇELIKKOL ${ }^{1}$ (])
}

${ }^{1}$ Assist. Prof., Bilkent University, Faculty of Humanities and Letters, Ankara, Turkey

ORCID: A.Ç. 0000-0003-3677-7308

\section{Corresponding author:}

Ayşe ÇELIKKOL

Bilkent Üniversitesi, İngiliz Dili ve Edebiyatı Bölümü, G 215-B, Bilkent, Ankara

E-mail: celikkol@bilkent.edu.tr

Submitted: 12.07 .2020

Revision Requested: 28.08.2020

Last Revision Received: 01.09.2020

Accepted: 08.10.2020

Citation: Celikkol, A. (2020). Gender, animals, and Gaskell's Cousin Phillis. Litera, 30(2), 307-324.

https://doi.org/10.26650/LITERA2020-0102

\section{ABSTRACT}

The so-called animal turn in the humanities has given rise to an increased interest in the ways in which representations of animals shape human cultures. In Victorian studies, scholars have attended to the significance of domestic pets and other animals in the production of Victorian ideologies and subjectivities. Recent studies often point out the role animals played in the formation of Victorian domesticity. While these studies in general assign a key role to animal figures in the mediation of traditional domesticity, this essay explores the opposite phenomenon taking place in the Victorian novelist Elizabeth Gaskell's Cousin Phillis, a novella in which pets and farm animals are prominent. In this work, the eponymous protagonist, a young woman living on a farm, falls in love with a cosmopolitan engineer. Rather than portraying Phillis as an ethereal angelic creature who would be typical of the ideal Victorian woman, Gaskell ascribes to her a passionate nature, though hidden behind a constrained façade. Phillis is partly able to express her deep-set emotions, including her interest in the cosmopolitan engineer, when interacting with animals. This non-traditional gender role becomes possible through the representation of birds and the family dog. Animals enable the imagination of a femininity that resists restrictive gender codes. The traditional association of animals with women has sometimes worked to denigrate the latter, but as Gaskell shows that this link also has an emancipatory potential.

Keywords: Animals, Cousin Phillis, domesticity, femininity, gender roles 


\section{Introduction}

In the traditional approach to gender roles in Western cultures, women tend to be associated with nature and men with culture (Ya-Chu Yang, 2017, p. 4). Even more specifically, women are considered to have an affinity with animals. As Lynda Birke and Luciana Parisi write, "the woman/animal association has long been problematic precisely because it is used in ways that devalue women" (1999, p. 58). Yet as Birke and Parisi also assert, the association can express "shared oppressions: nature, animals, and women suffer through the combined actions of various systems of domination" (1999, p. 58). In other words, patriarchal domination threatens nature and animals as it does women. Based on this latter dynamic, we may ask whether women's association with animals possesses an emancipatory potential even though it may have been historically used to denigrate women. The Victorian novelist Elizabeth Gaskell's novella Cousin Phillis suggests that women's connectedness to animals can indeed function to counter restrictive gender roles.

Although Gaskell is best known for her novels such as Mary Barton and North and South, Cousin Phillis is also noteworthy as it puts Gaskell's skills as a mature fiction-writer on display. In this novella, the eponymous heroine, leading an isolated life with her family, falls in love with an engineer who visits the farm on which she lives. She interacts intensely with birds and the family dog as she first falls in love with and is later abandoned by the engineer. Her association with the animals allows her to leave behind the traditional femininity that many Victorian texts, such as Coventry Patmore's The Angel in the House, ascribe to women. While traditional Victorian femininity demands that women remain passive, thanks to her association with the family dog and birds, Phillis assumes an active role in expressing emotions that are irreconcilable with traditional gender roles.

\section{Examining Animals in Victorian Studies}

Scholars in critical animal studies both explore the ways in which "a variety of animal species possess the basic capabilities deemed necessary for subjectivity" (Weil, 2010, p. 2) and inquire into what representations of animals reveal about human subjectivities, cultures, and ideologies. In Victorian studies, as in other humanities fields, scholars have been considering the roles that animals play in and beyond literary texts, noting their omnipresence in the literary imagination (Mazzeno \& Morrison, 2017). In Victorian Animal 
Dreams, Deborah Denenholz Morse and Martin A. Danahay explain that animal imagery sheds light on human identity: "Like the anthropologist Roy Willis, we are interested in 'what animals signify to man', and like historian and art critic Steve Baker, we examine questions of symbolic and rhetorical uses of animal imagery that both code and illuminate the subject of human identity in Western culture" $(2017$, p. 3). Representations of nonhuman animals are central to the literary imagination in part because they mediate human subjectivity'. What can animal imagery tell us about the human imagination that employs it? How do domestic and farm animals shape the identities of humans who interact with them? These are some questions that the present essay explores as it analyzes the representation of animals in Gaskell's Cousin Phillis, a novella about Phillis's broken heart, narrated through the perspective of one of her relatives.

Nonhuman animals leave their marks on our cultural artefacts. "Their lives [were] deeply imbricated in and influencing human culture and narrative," as Ivan Kreilkamp states in Minor Creatures (2018, p. 26). He asserts that animals have been central to meaning-making and identity-formation in Victorian texts, despite the creatures' seeming marginality: "animals do inhabit and even shape Victorian fiction in ways that have not been fully accounted for" $(2018$, p. 2). Animals have always been "a shaping influence" and are in this manner as important to Victorian fiction as to the lives that are depicted in it (2018, p. 2). Like Morse and Danahay's, Kreilkamp's approach to animals is informed by "the so-called nonhuman turn in recent critical practice" (Kreilkamp, 2018, p. 3), undertaken by Jacques Derrida, Cary Wolfe, and Jane Bennett among many others. As Bennett puts it, the goal in this new approach is to "find new techniques, in speech and art and mood, to disclose the participation of nonhumans in 'our' world" (quoted in Kreilkamp, 2018, p. 3). While the nonhuman turn is a late-twentieth and twenty-first century phenomenon, the Victorians themselves recognized the dependence of the human world on nonhuman animals, not only for the delineation of what it meant to be human but also for continually negotiating the meanings of home, friendship, and sympathy. From Charles Dickens's Oliver Twist and David Copperfield to Emily Brontë's Wuthering Heights and Thomas Hardy's Far From the Madding Crowd, Victorian fiction in which nonhuman animals figure prominently attest to this dynamic.

Literary criticism to the present day has often recognized the ways in which the companion animal makes traditional domesticity possible. For Harriet Ritvo and

1 Animal subjectivity is a central question in animal studies (Nagel, 1974), but is beyond the scope of this article, which instead turns to the effect of the animals on human subjectivity. 
Kreilkamp, domestic animals such as dogs were important to the construction of a domestic ideal in the Victorian period. Ritvo writes that "familiar domestic beasts ... most persuasively represented an orderly social hierarchy" (1987, p. 18). Kreilkamp expands this point: "Animals and pets become in the Victorian period not just instances and proofs of domesticity but constitutive of the concept. The sentimental Victorian home is created and maintained through the excessive affect lavished ... on pet animals" (2018, p. 31). To advocate the sentimental notion of home, it does not suffice to acquire and keep pets-people must produce narratives about these pets in which their presence becomes the cornerstone of a domestic existence. Literary critics triangulate fiction, pets, and domesticity to understand the influence of the nonhuman animal in the Victorian period. Philip Howell stresses the role that the pet, and in particular the dog, played in the creation of a particular kind of private life that was centered on the family in the Victorian period. Writing of "the historical incorporation of the companion animal into the domus itself," he writes that "[d]ogs became familiar because they came to be associated with the family, and with the private sphere of the home" $(2015, \mathrm{p}$. 17). Taking the link between domesticity and the companion animal as its point of departure, the present paper explores how nonhuman animals have also facilitated challenges to traditional domesticity.

\section{Elizabeth Gaskell and Animals}

Elizabeth Gaskell's attentiveness to the nonhuman animal, and especially to its interactions with the human, is evident in her fiction as well as nonfiction. Consider the references to animals in The Life of Charlotte Brontë, the posthumous biography Gaskell published in 1857, only seven years before Cousin Phillis. Gaskell first writes, "Charlotte was more than commonly tender in her treatment of all dumb creatures, and they, with that fine instinct so often noticed, were invariably attracted towards $\operatorname{her}^{\prime \prime}(1857$, p. 307). Then she distinguishes between several modes of interacting with animals, connecting each to a personality type:

The feeling, which in Charlotte partook something of the nature of affection, was, with Emily, more of a passion. Someone speaking of her to me ... said, "she never showed regard to any human creature; all her love was reserved for animals." The helplessness of an animal was its passport to Charlotte's heart; the fierce, wild, intractability of its nature was often what recommended it to Emily. (1857, p. 308) 
While Charlotte's attachment to animals conforms to the domestic ideal insofar as it affirms feminine tenderness and affection, Emily's interest in the animal stems from the opposite instinct, the desire to embrace the wilderness.

In an exploration of Gaskell's representation of animals that analyzes many of her works but not Cousin Phillis, Brenda Ayres notes that Gaskell's thinking about animals depended on contemporary science. Gaskell and Charles Darwin were cousins. Indeed, as Ayres argues, there are characters in Gaskell's fiction whose depictions are inspired by Darwin and his scientific career. Insects, for example, play an important role in Gaskell's novels, though not in the novella Cousin Phillis.

As Ayres argues, Gaskell's depictions of animals in Cranford, North and South, and Wives and Daughters "validate and empower women" (2018, p. 23). Ayres shows that, in these novels, a number of species from insects to cows affirm and boost women's agency. In Cranford, a character named Miss Betsey Barker has a cow, very dear to her, that falls into a lime-pit. After its rescue, the cow is cold, in response to which a male character proposes in jest that Miss Betsey Barker put flannel underwear and clothing on her-or else the cow will die. Surprisingly, dressing the cow in flannel is precisely what the owner of the cow decides to do. In this episode the cow "bring[s] out the resourcefulness and humanity" in Miss Betsey Barker (Ayres, 2018, p. 37). The significance of bees in North and South similarly points toward the issue of women's agency (Ayres, 2018, p. 32). The protagonist, Margaret Hale, receives the distressing news that she has to leave her hometown and move north; subsequently, she observes a bee exiting a flower, having collected pollen. The bee, notes Ayres, "is an agent that gives [Margaret] the strength to adapt" (2018, p. 33). Bees are also significant in Gaskell's last novel, Wives and Daughters. The female protagonist "feels great peace as she hears" the bees (Ayres 2018, p. 33). Moreover, the bees enable her to"puzzle[] out objects obscured by distance or shadow" (qtd in Ayres, 2018, p. 33). The enabling function of the bees in Wives and Daughters attests to the way animal and human agencies depend on one another.

While Ayres does not mention Cousin Phillis, Gaskell's interest in the connection between animals' and women's actions is at work in that work of fiction as well. This article aims to add to Ayres's argument not only by focusing on Cousin Phillis but also by considering a more diverse set of women's issues than agency alone, including desire, domesticity, marriage, and self-expression. 


\section{Cousin Phillis and Its Plot}

An enthusiastic participant in her family's farming rituals, the eponymous heroine of Elizabeth Gaskell's Cousin Phillis (1864) is intimately connected to the animals that surround her. Jeni Curtis finds that her alignment with nature, highlighted by the narrator Paul Manning, reinforces traditional gender roles:

Very early in his story, Paul also establishes Phillis in "the realm of nature." He finds her most acceptable with a backdrop of animals and birds with whom she can communicate, "tempting the timid downy chickens" onto her pinafore (241), rather than in the realm of culture and of books. This identification of Phillis and nature, of wordless communication with other little creatures, intensifies as Paul's story progresses. (1995, p. 134)

While it is true that Phillis's role in farming and her intimacy with animals become increasingly conspicuous as the novella unfolds, so does her connection to books, especially in foreign languages. Animal husbandry and book learning appear antithetical in Curtis's approach, but the novella points out the common ground between them through repeated references to Virgil's Georgics, which famously addresses farm labor. The experience of farming becomes inseparable from the act of reading literature in Latin. This inseparability points toward a peculiar subjectivity in which the young woman masters what is traditionally considered masculine -reading Latin - specifically because of her special connection to the natural world. Phillis understands Georgics well not only because she has received instruction in Latinbut also because she has become attuned to the challenges of farming through experience. In this manner, farming becomes a gateway to her interest in Latin and thus a means of introducing nontraditional femininity.

Phillis's alignment with the natural world does not diminish her agency as a young woman or place her in a constrained role predetermined by a rigid gender ideology. Phillis's privileged relation to the farm animals, the family pet, and birds, far from limiting the affective and cognitive possibilities that await her, are deeply enriching. Through the eponymous heroine, Cousin Phillis showcases the mutually-sustaining intimacy between humans and other animals and models a non-abusive relationship that is not reducible to consumerism. 
A brief summary of Cousin Phillis is in order as the novella is not as well-known as North and South or Mary Barton. The protagonist Paul Manning is a nineteen-year old clerk employed in the construction of a railroad branch from Eltham to Hornby. His father, a mechanic, is an inventor who secures for his son a situation above his own. Paul's boss is Mr. Holdsworth, an English engineer who, having lived on the Continent for years, resembles a foreigner in manners and appearance. Paul resides in the county town of Eltham but, encouraged by his mother, begins to visit Hope Farm in Heathbridge, where his relatives live. Ebenezer Holman, an Independent minister, lives on the farm with his family. Phillis, the only surviving child of the Holmans, is only two years younger than Paul, and as the two spend time together, he is as intimidated as charmed by her, in part because she can read Latin and Greek whereas he cannot. A conversation between Paul and his father reveals that Paul thinks Phillis would never accept him as a husband.

After Mr. Holdsworth is taken ill for a while, Paul takes him to Hope Farm and introduces him to the Holmans. The Reverend asserts that the farm will help Holdsworth to recuperate, and Paul's boss spends some time there while Paul returns to work. Holdsworth notices that Phillis has been trying to read Dante's Inferno and assists her by writing down the meanings of some words she does not know. His effort elicits a warm response from her, after which he starts giving her Italian lessons. Paul observes warm interactions between Holdsworth and Phillis. The two tenderly attend to one another on a rainy day when everybody takes shelter while hay-making. During harvest-time, when Holdsworth begins to make a portrait of Phillis as Ceres, the goddess of agriculture, she leaves the room suddenly after blushing. On a day of apple-gathering, Paul recognizes a "tender" and "passionate"'look of love in [Holdsworth's] eyes" (Gaskell, 1986, p. 273).

Later in the same day, Holdsworth receives a proposal to superintend a railway line in Canada and leaves shortly thereafter, but not before he confesses to Paul that he loves Phillis and intends to marry her upon his return in two years. Back on the farm, Paul notices that Phillis turns silent and pale after Holdsworth's sudden departure and one day witnesses her sobbing. In response, he reveals to Phillis Holdsworth's plans for the future. After hearing that Holdsworth loves her, Phillis's "tender mouth [is] curved with rapture" (Gaskell, 1986, p. 285). When Paul visits the Holmans on Easter, he recognizes a transformation in Phillis, whose "peaceful serenity" appears to be replaced by a "vivid happiness" (Gaskell, 1986, p. 291).

Paul and Holdsworth correspond, and the latter mentions meeting a French-Canadian woman who resembles Phillis. Soon another letter announces that Holdsworth is to 
marry that woman, and Paul realizes the marriage must have already taken place by the time he received the letter. Upon receiving the news, Paul regrets his past "indiscretion" (Gaskell, 1986, p. 293). When Phillis finds out about this marriage, instead of reacting negatively in any visible way, she absolves Paul, assuring him that he has not done anything wrong. Especially after the Holmans receive the wedding cards that Holdsworth sends them, Phillis displays signs of severe distress. When the minister asks Paul if Holdsworth has ever made love or promised marriage to her, Paul has to confess what he himself told her. Furious, the father blames Paul for "spoiling her peaceful maidenhood" (Gaskell, 1986, p. 307). Upon overhearing this conversation, Phillis tells her father that she loved Holdsworth and then falls ill, convulsing with what turns out to be a brain fever. After a trying episode, she recovers and asserts that she can and will "go back to the peace of the old days" (Gaskell, 1986, p. 317).

\section{Animal Connections Beyond Traditional Domesticity}

To be sure, Cousin Phillis in some ways adopts the use of the pet as a means of establishing what Kreilkamp calls sentimental domesticity. During an early visit that Paul pays to Hope Farm, he observes a scene in which the women assume traditional gender roles, with Phillis's mother Cousin Holman "mend[ing] stockings out of a high piled up basket" with her daughter helping her, in "tranquil monotony" (Gaskell, 1986, p. 242). The scene is complete with "the curled-up pussy cat sleeping on the hearth-rug" (Gaskell, 1986, p. 242), yet elsewhere Paul describes Phillis as "more like a man than a woman" as she knows Latin and Greek (Gaskell, 1986, p. 252). With this complex gender identity that complicates the traditional domesticity of the stock-mending scene, the curled-up pussy by the hearth will not suffice; the novella needs and delivers other cross-species interactions that match complex gender identities, rather than affirm the power of an idyllic hearth. While Kreilkamp provides ample evidence that the fictional representation of the pet was central to the making of domesticity, some interactions between humans and nonhuman animals point in the opposite direction and become the means of undoing the pressure of domesticity.

For many Victorians, proper femininity effaced the longings of the body ${ }^{2}$. The farmerminister of Cousin Phillis, whose Puritanism gives rise to the restrictions he places on

2 For the most part, this notion of traditional Victorian femininity was held as an ideal rather than constituting a lived experience. Coventry Patmore's The Angel in the House exemplifies the effacement of women's desire in literature. 
his daughter, participates in this trend. The daughter, while on good terms with her father, expresses a desire to transgress those restrictions. Indeed, both the daughter and the wife challenge the paternalistic farmer-minister:

"Phillis, I am thankful thou dost not care for the vanities of dress!" Phillis reddened a little as she said, in a low humble voice"But I do, father, I'm afraid. I often wish I could wear pretty coloured ribbons round my throat like the squire's daughters.

"It is but natural, minister!" said his wife;"I am not above liking a silk gown better than a cotton one myself!" (Gaskell, 1986, p. 252, p. 245)

Adorning the self is not welcomed by Holman and is dismissed as too worldly. The sensuality of the silk that his wife likes contrasts with the functionality of the cotton. The two types of cloth differ also in terms of cost, with the wife opting for the more luxurious. Interestingly, for the wife it is the longing for the silk and the richly colored ribbons that is "natural." Here, as elsewhere in the novella, nature is aligned with the sensual rather than with restrictive modesty.

Whatever her father's expectations may be, Phillis is not so much an angel of the house as a flesh-and-blood young woman whose playful interaction with the family dog adds to her physical charm. She and Rover form a noticeable duo, highly audible as well as visible: "At length she grew tired of their mutual play, and with a feint of striking him, and a 'Down, Rover! do hush!' she looked towards the window where we were standing, as if to assure herself that no one had been disturbed by the noise, and seeing us, she coloured all over" (Gaskell, 1986, p. 262). To hear and see Phillis when she is playing with Rover is to see her without the mask she wears when interacting with the young men. The animal counters the self-effacing tendency of an otherwise shy Phillis, and Holdsworth recognizes that condition as noteworthy. When she "hurri[es] away, with Rover still curving in sinuous lines about her as she walk[s]," Holdsworth declares, "I should have liked to have sketched her" (Gaskell, 1986, p. 262). In interacting with the dog, Phillis constructs a subjectivity that resists the angelic ideal.

The animals repeatedly pull the characters into a universe in which gender roles are relatively fluid. Consider, for instance, the pastoral experience that Paul narrates as the minister sings a psalm, "Come all harmonious tongues," beating time with a spade (Gaskell, 1986, p. 231). The materiality of farm labor mixes easily with the transcendence 
implicit in the act of singing the psalm. Even though the lyrics invite the believer to sing, Paul is inclined to remain silent:

There we five stood ... in the tawny stubblefield, from which all the shocks of corn had not yet been carried - a dark wood on one side, where the woodpigeons were cooing; blue distance seen through the ash-trees on the other. Somehow, I think that if I had known the words, and could have sung, my throat would have been choked up by the feeling of the unaccustomed scene. (Gaskell, 1986, p. 232)

This is a scene of contrasts: just as the dark wood meets the blue skies, the cooing woodpigeons and the singing girl find their opposite in Paul. The latter's intense - and passive - emotional response to the natural environment breaks down binary gender roles. If this scene feminizes Paul, the reverse is true with respect to Phillis's identity in a subsequent scene at the "farm-yard," in which the cousins bond with each other - and with the poultry, calves, and a cow (Gaskell, 1986, p. 241). Phillis is anything but prim or constrained:

We fed the poultry, she kneeling down with her pinafore full of corn and meal, and tempting the little downy chickens upon it, much to the anxiety of the fussy ruffled hen, their mother. She called to the pigeons, who fluttered down at the sound of her voice. She and I ... came back tired and hungry and dirty at dinner time. (Gaskell, 1986, p. 241)

As the chicks climb the pinafore, feminine propriety is replaced by cross-species interplay. In this experience of bonding, there are no binary gender codes, with Phillis playfully encouraging the chicks to try the limits placed by their mother.

Such scenes challenge Pearl L. Brown's argument that the pastoral in this novella fosters idealized femininity. "Gaskell reminds readers that the pastoral myth of the unspoiled bucolic landscape embodied in the image of the female idealized is a central metaphor," writes Brown (1992, p. 24). She reinforces the point in several ways, for instance by asserting that "[h]er father's pastoral withdrawal and religious beliefs come together to reinforce idealized feminine virtues" (1992, p. 25). Yet the episode in which Holdsworth makes a portrait of Phillis as Ceres during harvest-time reveals the opposite, that the pastoral energies of the novel are decidedly pagan in that they render her 
sensual rather than idealize her. Brown's point, that "the burial of her female self has been fostered in the pastoral idyll of Hope Farm" similarly belies the ways in which the pastoral world of Hope Farm allows Phillis to bypass the ethereal angel vs. sensual monster binary (1992, p. 25).

Phillis's and the family dog Rover's "mutual play" demonstrates that interactions with animals allow her to assert boundaries while at the same time establishing interconnection:

she had just finished her task, and was standing up, her back to us, holding the basket, and the basin in it, high in the air, out of Rover's reach, who was giving vent to his delight at the probability of a change of place by glad leaps and barks, and snatches at what he imagined to be a withheld prize. (Gaskell, 1986, p. 261)

This game positions Phillis as a figure of authority while at the same time she bonds with the family dog who enjoys the ritual. The interaction with the dog cultivates the skills and habits also employed in flirting: playfulness, the testing of boundaries, and mutual pleasure. This scene displays the dynamics that Kathryn Yeniyurt describes in her work. The interaction between a nonhuman animal and a human being may "approximate a kind of 'play;"' she asserts: "a human may only begin to imagine the nonhuman perspective after observing (and perhaps responding to) an extensive series of the animal's postures, movements, and sounds" (2017, p. 132). This kind of imagination is at work in Phillis's everyday life, thanks to the presence of Rover.

\section{Self-Expression and the Canine Companion}

After Holdsworth abandons Phillis to go to Canada, her bonding with Rover coincides with, and even expresses, a subjectivity in which female desire is a possibility. Tellingly, this transgression of idealized domesticity takes place outside the home; its energy and meaning cannot be contained by the domestic space. The space where the crossspecies bonding occurs is a locale in which Phillis can be herself:

I followed Phillis's example, and rushed out of the house. .. I followed till I came to a great stack of wood in the orchard ... and I recollected then how Phillis had told me, that first day when we strolled together, that 
underneath this stack had been her hermitage, her sanctuary, when she was a child. (Gaskell, 1986, p. 283)

When she wishes to leave behind the selfhood she performs in the domestic space, she retires to this locale. In this "hermitage," she experiences a symbiotic relationship with Rover.

The tableau that Paul encounters upon entering this sanctuary attests to his cousin and the dog's mutual attachment. At this stage in the novella, Phillis moves from simply befriending Rover to resembling him insofar as she, too, becomes animal-like. The animal sounds that she produces signal her distress, but they also bespeak a capacity for self-expression, however limited:

She was sitting on a log of wood, Rover by her. She had laid her cheek on Rover's head, and had her arm around his neck, partly for a pillow, and partly from an intrinsic craving for warmth on that bitter cold day. She was making a low moan, like an animal in pain, or perhaps more like the sobbing of the wind. Rover, highly flattered by her caress, and also, perhaps, touched by sympathy, was flapping his heavy tail against the ground[.] (Gaskell, 1986, p. 283)

Deprived of one attachment-Holdsworth--, Phillis finds another in her nonhuman companion. She needs Rover, for warmth, for friendship, for sympathy. The dog has what the human lacks--loyalty. When Phillis moans like an animal, her relation to the dog moves from metonymic (having to do with proximity) to metaphorical (having to do with similarity). Because as a young woman she cannot admit to being in love, she has to endure the pain of separation quietly at home. Her sentiments find expression in this non-domestic space in nonhuman language. The animal, then, gives her more than warmth: a language, however inarticulate, in which she can let her authentic sentiments rise to the surface. In her interactions with her parents, she does not disclose her deep emotions. She is thus most herself in her symbiosis with the nonhuman. In the sanctuary, she is able to own up to her passion rather than being confined to the less expressive selfhood she performs in human-dominated spaces. Poignantly, she must experience passionate womanhood in pain.

Subsequently comparing Phillis's distressed moan to the sobbing of the wind, Paul effaces his own recognition of the human-as-animal, attempting to reenter 
the realm of propriety from which the sanctuary was to offer relief. If in one moment the text asserts the common ground between Rover and Phillis, in the next it retracts the claim, as if to backpedal from the radical philosophical potential implicit in it.

As Morse and Danahay highlight, "the boundary between the animal and the human has long been unstable" (2017, p. 4). If, in our own era, Derrida famously questions the animal/human divide (2002), that inquiry can indeed be traced back to the Victorian period, as the fleeting metaphoric relation between the dog and the human suggests in Cousin Phillis. According to the literary critic Grace Moore, in Dickens's fiction, animals can reflect the emotions of women (2017). Moore writes, "In [Dickens's] Dombey and Son, Florence Dombey's dog Diogenes provides an unlikely outlet for his owner's repressed passions, bounding effusively towards Walter Gay at every possible

opportunity" (2017, p. 206). A similar phenomenon takes place in Gaskell's work, with a repressed female character finding a striking albeit inarticulate voice through her metonymic and metaphorical relation to the canine.

\section{Birds and Passionate Selfhood}

When Phillis is content, she resembles the nonhuman animal, just as she does when she is in distress. She contrasts to the ethereal, angelic woman with her newly budding passion for Holdsworth, and her connection to the animal world deepens even as she grows more committed to him. Cousin Phillis does not treat the passionate woman's entry into the animal world as a sign of fallenness or as a descent to be lamented. To the contrary, it celebrates it as a signal of the unity of life forms.

Hearing of Holdsworth's love for her transforms Phillis. In her "heavenly happiness," Phillis's mouth is "curved with rapture," which indicates that the asexual existence allotted to the ideal Victorian woman is absent in this novella (Gaskell, 1986, p. 285). In that state, Phillis does not just resemble a bird, but speaks as one:

I think she hardly knew why she was so happy all the time... I can see her now ... intent on sweet mockery of some bird in a neighboring bush or tree. She had the art of warbling, and replying to the notes of different birds, and knew their song, their habits and ways, more accurately than anyone else l ever knew. She had often done it at my request the spring 
before; but this year she really gurgled, and whistled, and warbled just the way they did, out of the very fullness and joy of her heart. (Gaskell, 1986, p. 289)

Phillis does not just know birds or communicate with them but does so in their language. The novella, which has always depicted her as multilingual, adds a new twist to her multilingualism here. The heart, awakened to the joy of mutual love, compels her to communicate with the birds as one of them. Cross-species communication reveals the joys of attachment across difference. She and Holdsworth are also very different in their backgrounds and personalities, but attached to one another-or so thinks Phillis at this stage.

Though the most readily available depiction of womanhood as animal-like was found in the image of the fallen woman in this era, Gaskell's portrayal of a passionate woman in harmony with the animal world presents an alternative way of identifying flesh-and-blood womanhood with the animal. The Pre-Raphaelite poet and artist Dante Gabriel Rossetti's unfinished painting "Found" (1865-1869), produced at around the same time as Cousin Phillis, serves to contextualize Gaskell's innovation. In this painting, a male figure holds the hands and wrists of a red-haired woman who leans on a brick wall, half reclined with her eyes closed. The woman's literal inability to stand erect signals her status as a fallen woman. Rossetti explicitly wrote of the "shame" of the woman who appears to be a prostitute:

The picture represents a London street at dawn, with the lamps still lighted along a bridge which forms the distant background. A drover has left his cart standing in the middle of the road (in which, i. e. the cart, stands baa-ing [sic.] a calf tied on its way to market), and has run a little way after a girl who has passed him, wandering in the streets. He has just come up with her and she, recognising him, has sunk under her shame upon her knees, against the wall of a raised churchyard in the foreground, while he stands holding her hands as he seized them, half in bewilderment and half guarding her from doing herself a hurt. (qtd. in Nochlin, 1978, p. 139)

The woman's similarity to the calf in the background is two-fold: she, too, is bought and sold on a market, and she, too, is trapped, though the net that constrains her is not visible. In "Found," the metaphorical link between the calf and the sexualized woman 
suggests that the woman has been reduced to an animal. In Cousin Phillis, on the other hand, the connection to other life forms elevates the woman into an existence more fulfilling than the role of the ethereal angel. The novella reveals that the woman-animal comparison was not limited to the figure of the fallen woman in the Victorian period and that the depiction of the animalistic side of a woman does not have to render her pitiful.

\section{Cross-Species Connection, a Familial Habit}

Phillis's intimacy with animals is part and parcel of her subtle, quiet rejection of normative femininity. Her passion, indicated especially by her conversation with the birds, challenges the Puritan norms of her father. Yet her father's own closeness to animals serves as an unorthodox experience that clashes with rigid social expectations. Holman, a devout man whose prayers assume unconventional form, concludes his evening prayers with a blessing: "He prayed for the cattle and live creatures" (Gaskell, 1986, p. 239). This prayer unites the man's dual occupation as farmer and minister, as it is both an expression of his faith and his love for the animals. Praying specifically for the cattle makes it possible to then pray for all living creatures. In that sense, farming presents a gateway to appreciating creation. However devout the animal-prayer may be, Mr. Holman's love for animals is considered sinful by some. Another minister, Brother Robinson, condemns Mr. Holman's relation to the animals and singles it out as the reason for his daughter's suffering. During Phillis's illness, Robinson openly accuses Holman of being too worldly for his own good:

[A]fter a short time and some more shakes of the head, Robinson began again, --

"Secondly, we would have you listen to the voice of the rod, and ask yourself for what sins this trial has been laid upon you; whether you may not have been too much given up to your farm and your cattle; whether this world's learning has not puffed you up to vain conceit and neglect of the things of God; whether you have not made an idol of your daughter?" (Gaskell, 1986, p. 313)

The novella as a whole reveals that Robinson is wrong; the connection to the cattle reinforces Holman's faith rather than undermining it, yet Robinson's reaction clearly demonstrates the extent to which the connection to nonhuman animals turns Holman 
into a target. According to Robinson, Holman's closeness to his daughter falls into the same category as his love for the animals - presumably a distraction from true faith.

Robinson's comment shows how special Holman's connection to the animals is. The farmer-minister's wife partakes of the family tradition, as her love for the farm animals surfaces in her admiration for what the cattle can produce. She treats milk as Daisy's gift to their guest: "tell him [Holdsworth] there is new milk and fresh eggs to be had for the asking; it's luck Daisy has just calved, for her milk is as good as other cows' cream" (Gaskell, 1986, p. 256). The farmer-minister's wife does not question the humans' confiscation of the milk and the eggs, assured that the cattle and the poultry work for the humans. Her treatment of the family cow displays an awe for that animal's capacity to provide for its offspring and please humans at the same time. Phillis's connection to nonhuman animals, then, both reflects and extends her parents' treatment of the cattle. Like her parents, she enjoys a special connection to the animals. While that connection does not induce transgressive gender identities for the parents, for her, bonding with the dog and the birds helps to construct a self at odds with angelic femininity.

\section{Conclusion}

In Victorian studies, as in other fields in the humanities, the animal turn has recently inspired deep interest in transformative interactions between humans and other animals. Long before the rise of animal studies in academia, the Victorians were attuned to the entanglement of humans with other species, noticing how they influenced each other and shaped each other's lives. Elizabeth Gaskell's Cousin Phillis demonstrates the author's attentiveness to animal-human intimacy and especially to its influence on gender roles. Whereas recent criticism has stressed that nonhuman animals helped construct Victorian domesticity, Gaskell's novella shows that they also challenged traditional gender roles, especially as they called into question the emotional and behavioral constraints placed on women. The eponymous protagonist's identification with birds and the family dog enables her to express her feelings for a young man who abandons her, in ways that go against traditional Victorian femininity. Through that identification, she becomes an embodied subject with needs and desires, one who has little resemblance to the ethereal angelic being that some Victorian texts such as Coventry Patmore's The Angel in the House imagined, yet Phillis is not a fallen woman, as the novella does not treat her as impure or sinful. If the female figure commonly associated with animals was the fallen woman in the Victorian period, Cousin Phillis 
offers an alternative model wherein the resemblance to the animal is not always a cause for pity. Phillis longs for the young man who abandons her in ways that undermine the constraining effects of idealized femininity. Especially through Phillis's conversation with the birds, the text celebrates cross-species interconnection and its potential for unsettling the traditional economy of desire that prevailed in the Victorian period.

Gaskell's feat speaks to some critical concepts that are under fervent debate in our own times. Ecocriticism seeks to dismantle binaries such as nature / culture that historically made the association of women with nature possible (Kerridge, 2014, p. $367)$. In the 1980s and 90 s, critics and theorists became especially wary of the idea that women are particularly close to nature:

theorists began to openly express the dangers of the prior essentialist conceptualizations of the woman/nature analogy ... They ... criticized the essentialist and reductionist view of women that conceived them in terms of their reproductive, nurturing, and caring abilities, which naturally connected them to Mother Earth (Estévez-Saá \& Lorenzo-Modia, 2018, p. 128).

The association of women with nature at times ascribes to women such negative traits as passivity and lack of intelligence or confines them to traditionally feminine roles such as caring for others. For these reasons, the alignment of women with nature is often suspect; however, Gaskell's imagination of the intimacy between a young woman and the animals that surround her challenges this pattern. In this novelist's version, nature is active and dynamic rather than passive or static, and the connection to animals makes nontraditional gender roles possible. This character flourishes and comes to express herself through her interactions with birds and the family dog. As such, Gaskell suggests that the intimate link between women and nonhuman animals is neither denigrating nor constraining but instead potentially emancipatory.

Peer-review: Externally peer-reviewed.

Conflict of Interest: The author has no conflict of interest to declare.

Grant Support: The author declared that this study has received no financial support.

Hakem Değerlendirmesi: Dış bağımsız.

Çıkar Çatışması: Yazar çıkar çatışması bildirmemiştir.

Finansal Destek: Yazar bu çalışma için finansal destek almadığını beyan etmiştir. 


\section{References}

\section{Primary Sources}

Derrida, J. (2008). The Animal That Therefore I Am. New York: Fordham University Press.

Gaskell, E. (1857). The Life of Charlotte Brontë, Vol 1, London: Smith, Elder, and Co.

---. (1986). Cranford/Cousin Phillis. London: Penguin Books.

---. (2008). North and South. New York: Oxford University Press.

---. (2008). Wives and Daughters. New York: Oxford University Press.

\section{Secondary Sources}

Ayers, B, (2018). Gaskell's Activism and Animal Agency. In Ayers (Ed.), Victorians and Their Animals: Beast on a Leash (pp. 23-44). London: Routledge.

Birke, L. \& Parisi, L. (1999). Animals, Becoming. In P. Steeves (Ed), Animal Others: Ethics, Ontology, and Animal Life (pp. 55-73). Albany: State University of New York Press.

Brown, P. L. (1992). The Pastoral and Anti-Pastoral in Elizabeth Gaskell's Cousin Phillis. The Victorian Newsletter 82, pp. 22-5. Curtis, J. (1995). Manning the World: The Role of the Male Narrator in Elizabeth Gaskell's Cousin Phillis. Victorian Review, 21(2), pp. 128-44.

Estévez-Saá, M., Lorenzo-Modia, M. J. (2018). The Ethics and Aesthetics of Eco-caring: Contemporary Debates on Ecofeminism(s). Women's Studies: An Interdisciplinary Journal, 47(2), pp. 123-46.

Howell, P. (2015). At Home and Astray: The Domestic Dog in Victorian Britain. Charlottesville: The University of Virginia Press.

Kerridge, R. (2014). Ecocritical Approaches to Literary Form and Genre: Urgency, Depth, Provisionality, Temporality. In Garrard (Ed.), The Oxford Handbook of Ecocriticism (pp. 362-376). London: Oxford University Press.

Kreilkamp, I. (2018). Minor Creatures: Persons, Animals, and the Victorian Novel. Chicago: The University of Chicago Press.

Mazzeno L. \& Morrison R. (2017). Introduction. In Mazzeno and Morrison (Eds.), Animals in Victorian Literature and Culture (pp. 1-17). Basingstoke: Palgrave Macmillan.

Moore, G. (2017). Beastly Criminals and Criminal Beasts: Stray Women and Stray Dogs in Oliver Twist. In Morse and Danahay (Eds.), Victorian Animal Dreams: Representations of Animals in Victorian Literature and Culture (pp. 201-14). New York: Routledge.

Morse, D. M. \& Danahay, M. (2017). Introduction. In Morse and Danahay (Eds.), Victorian Animal Dreams: Representations of Animals in Victorian Literature and Culture (pp. 1-12). New York: Routledge.

Nagel, T. (1974). "What Is It Like To Be a Bat?" The Philosophical Review, 83(1), 435-50.

Nochlin, L. (1978). “Lost and Found: Once More the Fallen Woman." Art Bulletin 60, 139-53.

Ritvo, H. (1989). The Animal Estate: The English and Other Creatures in Victorian England. Cambridge: Harvard University Press.

Weil, K. (2010). "A Report on the Animal Turn." differences: a Journal of Feminist Cultural Studies, 21(2), 1-23.

Ya-Chu Yang, Karen. (2018) Introduction. In Vakoch and Mickey (Eds.), Women and Nature? Beyond Dualism in Gender, Body, Environment (pp. 3-10). New York: Routledge.

Yeniyurt, K. (2017). “Black Beauty: The Emotional Work of Pretend Play." In Mazzeno and Morrison (Eds.), Animals in Victorian Literature and Culture (pp. 233-49). Basingstoke: Palgrave Macmillan. 